\title{
PRODUCT VS. PRODUCTION DEVELOPMENT II - INTEGRATED PRODUCT, PRODUCTION, MATERIAL AND JOINT DEFINITION
}

\author{
Stoffels, Pascal; \\ Kaspar, Jerome; \\ Vielhaber, Michael \\ Saarland University
}

\begin{abstract}
As product, production systems and material strongly influence each other, an integrated view on these domains offers huge potentials during development in order to adjust characteristics being mutually dependent. Considering manufacturing aspects within the design process certainly constitute a widespread approach to make sure that the products can be produced to predefined costs and quality. As product characteristics are realised through material characteristics and manufacturing processes, material aspects need to be integrated into this view. Moreover, different geometries have to be assembled in order to create particular structures, why joints devote a special attention.

For this reason, a definition approach that integrates product, production systems, material plus joints and considers the ecological performance apart from the regular technical and economic aspects offers a huge potential for successful future solutions. This paper reviews relevant development approaches as well as supporting IT tools in the different domains. As a result, an extendedly integrated view is introduced and a method that supports the integrated selection of solutions regarding a technical, economic and ecological performance is introduced.
\end{abstract}

Keywords: Integrated product development, Concurrent Engineering (CE), Design methods

\section{Contact:}

Stoffels, Pascal Dominik

Saarland University

Institute for Engineering Design

Germany

pascal.stoffels@t-online.de 


\section{INTRODUCTION}

In light of today's challenging world with more and more complex demands on products and services (e.g. regarding productivity, efficiency and sustainability), prospective systems engineering approaches may no longer just take into account a separate product, production and material development, but rather evoke an integrated view on all these domains in order to exploit the whole potentials of its interaction.

Having this in mind, the adequate consideration of manufacturing aspects within the design process is a widespread approach to make sure that products can be produced to predefined costs and quality.

As product characteristics are realised through it manufacturing processes and the used material, the often-unappreciated material aspects need to be integrated into an early evaluation. Not enough with that, however, different geometries have to be connected in order to create particular structures as well as parts are added to assemblies, which leads to a particularised focus on the joint section design along with its intrinsic technology selection.

Figure 1 shows the definition process of product, material, production system and joints along the lifecycle of product and production system. The characteristics that are defined in the different phases within the definition processes influence the lifecycles to a high degree. While costs and quality were the main criteria for an assessment over the past years, ecological criteria get more and more in focus.

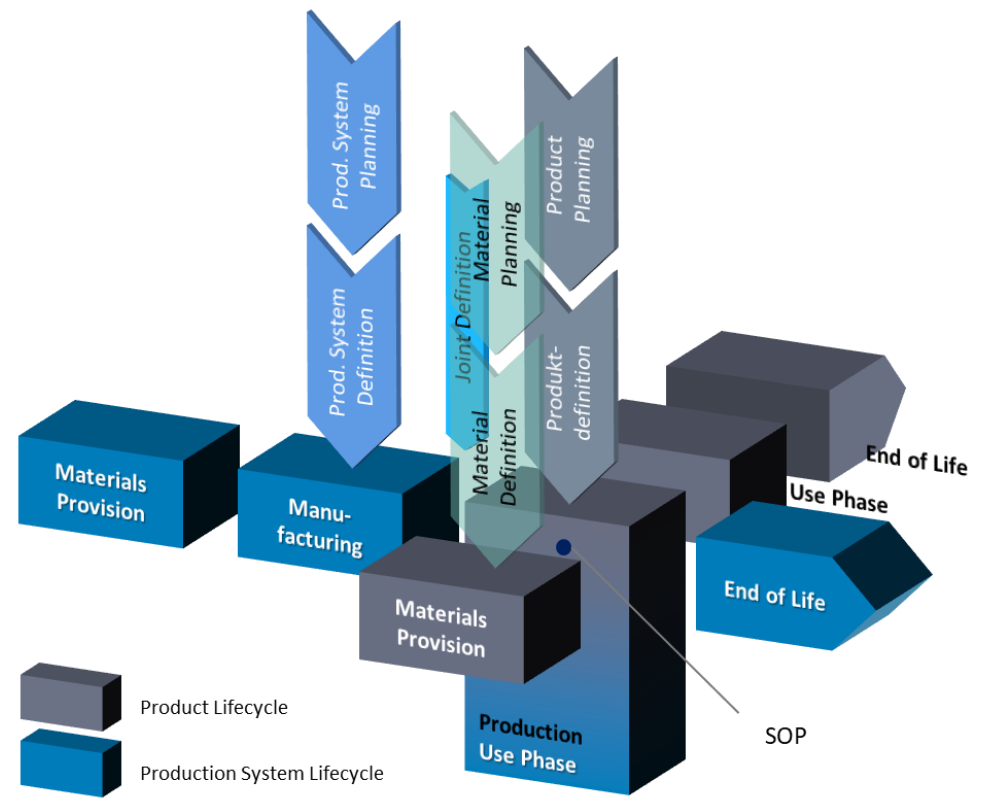

Figure 1. Intersection of the product and production system lifecycle with the respective definition phases, based on Vielhaber and Stoffels (2014) as well as Stoffels et al. (2015)

For this reason, a holistic definition approach that integrates product, material, production system and its joints while considering an optimised technical, economic and ecological performance offers a huge potential for successful solutions in the future.

This paper extends the existing concept of an integrated product, production and material definition of Stoffels et al. (2015) by integrating joints.

It is structured as followed. First, development approaches as well as supporting IT-Tools concerning domains, relevant for this contribution, are reviewed (section 2). Subsequently, an extended integrated view is represented (section 3). Section 4 introduces a method that supports the integrated selection of solutions regarding technical, economic and ecological performance. The paper will finally be concluded by a short summary and outlook.

\section{STATE OF THE ART AND LITERATURE REVIEW}

In this section, structure from an extract of established approaches and methodologies in the abovementioned domains is analysed, ensuing a furtherly unified categorisation of the individual development phases. 


\subsection{Product development}

While analysing popular product development approaches, a common structure can be identified (see Table 1). Beginning with the specification of a product, in this phase initial requirements to the product are defined and constraints (i.e. environmental, legal, technical, etc.) are determined.

In a second step, the reviewed approaches include a concept development. VDI 2221 (1993) methodology demands identification of product functions that require respective principle solutions. The arrangement of these principle solutions represents a potential concept. Suh (1990) provides a mapping of defined design parameters and process variables to the functional requirements, defined in the specification phase. These elements represent a conceptual solution. Most approaches are complemented by a subsequent assessment and selection procedure to accentuate the overall best concept.

In the next step, the previously developed concept will be detailed and designed. In the VDI221 guideline, a decomposition into feasible modules is emphasised that are subsequently integrated to the entire product and documented to be produced at the end.

Table 1. Overview of established approaches and methodologies within the domain of product development, based on Stoffels (2017)

\begin{tabular}{|c|c|c|c|c|c|}
\hline & VDI2221 (1993) & $\begin{array}{c}\text { Ulrich \& Eppinger } \\
\text { (2008) }\end{array}$ & $\begin{array}{c}\text { Akao (1990)/Hauser } \\
\text { \& Clausing (1988) }\end{array}$ & Suh (1990) & Weber (2005) \\
\hline \multirow{2}{*}{ 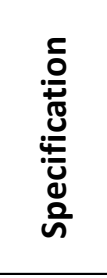 } & Definition & $\begin{array}{c}\text { Concept } \\
\text { Development }\end{array}$ & $\begin{array}{l}\text { Requirements } \\
\text { Definition }\end{array}$ & $\begin{array}{l}\text { Determination of } \\
\text { Functional } \\
\text { Requirements }\end{array}$ & $\begin{array}{l}\text { Analysis of the } \\
\text { requirements }\end{array}$ \\
\hline & $\begin{array}{c}\text { Clarification and } \\
\text { specification of the } \\
\text { scope }\end{array}$ & $\begin{array}{l}\text { Identification of } \\
\text { customer needs }\end{array}$ & $\begin{array}{l}\text { Determination of the } \\
\text { customer attributes }\end{array}$ & $\begin{array}{l}\text { Determination of } \\
\text { Functional } \\
\text { Requirements FRs } \\
\text { and constraints }\end{array}$ & $\begin{array}{l}\text { Determination of } \\
\text { Required Properties }\end{array}$ \\
\hline \multirow[b]{2}{*}{ 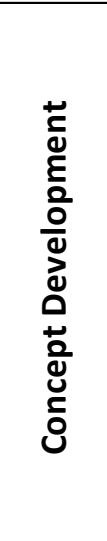 } & Draft & $\begin{array}{c}\text { Concept } \\
\text { Development/ } \\
\text { System } \\
\text { Development }\end{array}$ & $\begin{array}{c}\text { Concept } \\
\text { Development }\end{array}$ & $\begin{array}{c}\text { Concept } \\
\text { Development }\end{array}$ & $\begin{array}{c}\text { Concept } \\
\text { Development }\end{array}$ \\
\hline & $\begin{array}{l}\text { Identification of } \\
\text { functions and their } \\
\text { structures } \\
\text { Search for solution } \\
\text { principles and their } \\
\text { structures }\end{array}$ & $\begin{array}{l}\text { Development of } \\
\text { alternative concepts } \\
\text { Development of } \\
\text { product architecture }\end{array}$ & $\begin{array}{c}\text { Determination of the } \\
\text { Engineering } \\
\text { Characteristics }\end{array}$ & $\begin{array}{c}\text { Mapping of defined } \\
\text { Design Parameter } \\
\text { DPs and Process } \\
\text { Variables PVs }\end{array}$ & $\begin{array}{c}\text { Determination of the } \\
\text { major characteristics } \\
\text { (synthesis) } \\
\text { Analysis of the } \\
\text { resulting properties } \\
\text { Identification of } \\
\text { optimizing potential }\end{array}$ \\
\hline \multirow[b]{2}{*}{ 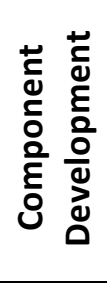 } & Design of Modules & Detail Development & Parts Deployment & Decomposition & Detail Design \\
\hline & $\begin{array}{l}\text { Structure into } \\
\text { feasible modules } \\
\\
\text { Design of the } \\
\text { relevant modules }\end{array}$ & $\begin{array}{l}\text { Detailed and } \\
\text { embodiment design }\end{array}$ & $\begin{array}{c}\text { Determination of the } \\
\text { crucial part } \\
\text { characteristics }\end{array}$ & $\begin{array}{l}\text { Decomposition of } \\
\text { Functional } \\
\text { Requirements, } \\
\text { Design Parameters } \\
\text { and Process } \\
\text { Variables } \\
\end{array}$ & $\begin{array}{l}\text { Refinement of the } \\
\text { characteristics with } \\
\text { analysis and } \\
\text { synthesis steps }\end{array}$ \\
\hline \multirow{2}{*}{ 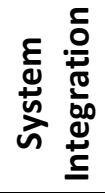 } & Design & & & & \\
\hline & $\begin{array}{c}\text { Design of the entire } \\
\text { product }\end{array}$ & & & & \\
\hline
\end{tabular}

\subsection{Production System Development}

In the production domain, also the development of production systems follows a common structure as described in established approaches, see Table 2.

In a first step, here the market and competitor's situation are analysed and the requirements are derived in most of the reviewed methodologies. Based on these constraints, the reviewed approaches develop a first production concept, where the scope varies from the definition of processes and sequence through a complete layout design to the final definition of modules and machines. In doing so, Wu (1994) 
additionally considers logistic aspects, whereas Spur (1994) includes an organisation planning. Suh's (1995) approach is based on the axiomatic design methodology from product development, but both design parameters and process variables are assigned to the functional requirements being defined in the specification phase.

Subsequently, the generated concept is detailed in the reviewed approaches. For this purpose, components (i.e. machines, factory automation, etc.) will be designed and allocated, while used manufacturing technologies will be detailed.

On this way, Gu et. al (2001) and VDI 4499 (2008) guideline also provide a comprehensive evaluation of the entire production system in a final step.

Table 2. Overview of established approaches and methodologies within the domain of production system development, based on Stoffels (2017)

\begin{tabular}{|c|c|c|c|c|c|c|c|c|}
\hline & $\begin{array}{c}\text { Eversheim } \\
\text { (2002), Minolla } \\
\text { (1975) }\end{array}$ & REFA (1990) & $\begin{array}{c}\text { Bellgran \& } \\
\text { Säfsten (2010) }\end{array}$ & Suh (1995) & $\begin{array}{l}\text { Gu et al. } \\
\text { (2001) }\end{array}$ & $\begin{array}{l}\text { VDI4499 } \\
(2008)\end{array}$ & Wu (1994) & Spur (1994) \\
\hline \multirow[b]{2}{*}{ 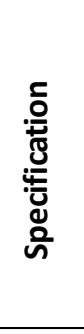 } & & $\begin{array}{l}\text { Preliminary } \\
\text { Planning } \\
\end{array}$ & $\begin{array}{l}\text { Preparation/ } \\
\text { Analysis }\end{array}$ & $\begin{array}{l}\text { Definition of } \\
\text { Requirements }\end{array}$ & $\begin{array}{l}\text { Definition of } \\
\text { Requirements }\end{array}$ & & $\begin{array}{l}\text { Analysis of } \\
\text { situation }\end{array}$ & \\
\hline & & $\begin{array}{c}\text { Situation } \\
\text { analysis, } \\
\text { definition of } \\
\text { objectives }\end{array}$ & $\begin{array}{c}\text { Analysis of } \\
\text { market and } \\
\text { development } \\
\text { potential and } \\
\text { the exising } \\
\text { production } \\
\text { system }\end{array}$ & $\begin{array}{l}\text { Definition of } \\
\text { Functional } \\
\text { Requirements } \\
\text { FRs \& } \\
\text { Constraints }\end{array}$ & $\begin{array}{l}\text { Definition of } \\
\text { Functional } \\
\text { Requirements } \\
\text { FRs \& } \\
\text { Constraints }\end{array}$ & & $\begin{array}{c}\text { Analysis of the } \\
\text { market }\end{array}$ & \\
\hline \multirow[b]{2}{*}{ 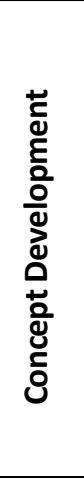 } & $\begin{array}{l}\text { Workflow } \\
\text { Planning }\end{array}$ & $\begin{array}{l}\text { Rough } \\
\text { Planning }\end{array}$ & $\begin{array}{c}\text { Concept } \\
\text { Development }\end{array}$ & $\begin{array}{c}\text { Concept } \\
\text { Development }\end{array}$ & $\begin{array}{l}\text { Concept \& } \\
\text { Configuration } \\
\text { Development }\end{array}$ & $\begin{array}{c}\text { Concept } \\
\text { Development }\end{array}$ & $\begin{array}{c}\text { Concept } \\
\text { Development }\end{array}$ & $\begin{array}{l}\text { Production } \\
\text { System } \\
\text { Planning }\end{array}$ \\
\hline & $\begin{array}{l}\text { Definition of } \\
\text { the processes } \\
\text { \& sequence }\end{array}$ & $\begin{array}{c}\text { Definition of } \\
\text { the processes, } \\
\text { assessment } \\
\text { and selection } \\
\text { of solutions } \\
\text { options }\end{array}$ & $\begin{array}{l}\text { Definition of } \\
\text { modules, } \\
\text { operations } \\
\text { and processes }\end{array}$ & $\begin{array}{l}\text { Mapping of } \\
\text { Design } \\
\text { Parameters } \\
\text { DPs and } \\
\text { Process } \\
\text { Variables PVs }\end{array}$ & $\begin{array}{c}\text { Determination } \\
\text { of operations, } \\
\text { machines and } \\
\text { components } \\
\text { Layout design } \\
\text { Mapping of } \\
\text { DPs and PVs } \\
\text { to FRs }\end{array}$ & $\begin{array}{l}\text { Layout design, } \\
\text { Determination } \\
\quad \text { of } \\
\text { technologies }\end{array}$ & $\begin{array}{l}\text { Arrangement } \\
\text { of the manu- } \\
\text { facturing, } \\
\text { logistics and } \\
\text { control } \\
\text { functions }\end{array}$ & $\begin{array}{c}\text { Planning of } \\
\text { organisation, } \\
\text { material flow, } \\
\text { processes and } \\
\text { resources }\end{array}$ \\
\hline \multirow{2}{*}{ 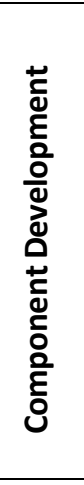 } & $\begin{array}{c}\text { Work System } \\
\text { Planning / } \\
\text { Production } \\
\text { ressource } \\
\text { design } \\
\end{array}$ & Detail Planning & Detailing & $\begin{array}{c}\text { Decomposition } \\
\text { of Concept }\end{array}$ & $\begin{array}{l}\text { Detailed } \\
\text { Design }\end{array}$ & $\begin{array}{l}\text { Component } \\
\text { Design }\end{array}$ & Design & $\begin{array}{l}\text { Production } \\
\text { System Design }\end{array}$ \\
\hline & $\begin{array}{l}\text { Determination } \\
\text { of the } \\
\text { resources, } \\
\text { layout and } \\
\text { logistics }\end{array}$ & $\begin{array}{l}\text { Detailing of } \\
\text { subsystems }\end{array}$ & $\begin{array}{l}\text { Detailing of } \\
\text { the concept }\end{array}$ & $\begin{array}{c}\text { De- } \\
\text { composition } \\
\text { of Functional } \\
\text { Requirements, } \\
\text { Design } \\
\text { Parameters } \\
\text { and Process } \\
\text { variables } \\
\end{array}$ & $\begin{array}{l}\text { Refinement of } \\
\text { components }\end{array}$ & $\begin{array}{c}\text { Design of the } \\
\text { production } \\
\text { facilities }\end{array}$ & $\begin{array}{l}\text { Selection and } \\
\text { allocation of } \\
\text { components }\end{array}$ & $\begin{array}{l}\text { Design of the } \\
\text { required } \\
\text { components }\end{array}$ \\
\hline \multirow[b]{2}{*}{ 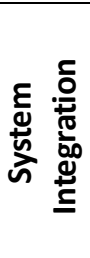 } & & & & & $\begin{array}{c}\text { Design } \\
\text { Evaluation }\end{array}$ & $\begin{array}{c}\text { Virtual } \\
\text { Comissioning }\end{array}$ & & \\
\hline & & & & & $\begin{array}{c}\text { Com- } \\
\text { prehensive } \\
\text { evaluation of } \\
\text { the system } \\
\text { design }\end{array}$ & $\begin{array}{l}\text { Verification of } \\
\text { the interplay } \\
\text { of hardware } \\
\text { and software }\end{array}$ & & \\
\hline
\end{tabular}

\subsection{Material selection}

The selection of appropriate materials within the development process is a challenging task, as there is an enormous number of materials with different properties available. An internationally recognised methodical approach for material selection, supported by a particular IT tool is presented by Ashby (2005). Ashby translates material-related design requirements into specific material properties. 
Subsequently, the entire solution space of materials is screened by using constraints and material indices. A material index represents the ratio between two specific material properties. The Cambridge Engineering Selector (CES Selector, Granta Design (2020)) can be used for this purpose.

\subsection{Joints}

The selection of joints is a rather neglected topic within the development process; however, it truly is a key factor for future multi-material design (Kaspar et al., 2018). Nevertheless, and apart from a systematic evaluation approach by Kaspar et al. (2018), Rusitschka (2017) presents an approach to select detachable joints. The approach starts with the definition of the solution space. A joint is described as an element that connects two parts. Parts constitute from geometry and material, whereas a joint contains information about the joint principle and the joining process. Potential solutions that fulfil the requirements are subsequently evaluated related to costs.

\subsection{Tools in product and production system development}

Apart from the purely theoretical approaches, there is a wide range of software tools that are used within the development processes of product and production system, see Table 3. At the interface between both domains, product life cycle management (PLM) or simply product data management (PDM) tools are the fundamental basis for the information exchange. In addition, environmental impacts can be calculated with life cycle assessment tools ensuing even more precise results as the development process progresses. Against this background, also material and process databases provide a basis for the selection of appropriate materials in combination with its applicable manufacturing technologies.

Having a deeper look to the product development, especially the specification phase is supported by requirements management tools in order to consider requirements consistently during the process. Based on that, SysML tools enable the generation of concepts and finally 3D-CAD come up with the more detailed design of components, whereas multiple simulation possibilities (i.e. FEA, CFD, etc.) analyse the presumptive properties.

In the field of production systems development, 2D-CAD, 3D-CAD and layout planning tools support the generation of concepts. CAD-Tools supplemented with electrical engineering tools are used in for the design of components. The interplay between the different components as well as the properties are analysed with simulation tools (i.e. NC-simulation, robotics simulation, PLC simulation, etc.).

Table 3. Overview of established tools for product and production systems development

\begin{tabular}{|c|c|c|c|}
\hline & Product Definition & & Production Definition \\
\hline Specification & $\begin{array}{c}\text { Requirements Management } \\
\text { Tools }\end{array}$ & \multirow{7}{*}{ 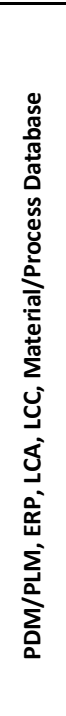 } & \\
\hline \multirow{2}{*}{$\begin{array}{l}\text { Concept } \\
\text { Develop- } \\
\text { ment }\end{array}$} & SysML Tools, 3D-CAD & & $\begin{array}{l}\text { 2D-CAD, 3D-CAD, } \\
\text { Layout Planning }\end{array}$ \\
\hline & Modelica Tools & & $\begin{array}{l}\text { Material Flow Simulation, } \\
\text { Cycle Time Analysis, Logistics } \\
\text { Simulation }\end{array}$ \\
\hline \multirow[b]{2}{*}{$\begin{array}{l}\text { Component } \\
\text { Develop- } \\
\text { ment }\end{array}$} & 3D-CAD & & $\begin{array}{l}\text { 2D-CAD, 3D-CAD, } \\
\text { Electrical Engineering }\end{array}$ \\
\hline & $\begin{array}{c}\text { FEA, Multi Body Simulation } \\
\text { (MBS), Computational Fluid } \\
\text { Dynamics (CFD) }\end{array}$ & & $\begin{array}{c}\text { NC Simulation, Robotics } \\
\text { Simulation (Collision Detection, } \\
\text { Accessability Studies, Physics), } \\
\text { PLC Simulation }\end{array}$ \\
\hline \multirow{3}{*}{$\begin{array}{c}\text { System } \\
\text { Integration }\end{array}$} & & & \\
\hline & & & Virtual Comissioning (SiL, HiL) \\
\hline & \multicolumn{3}{|c|}{ Full LCA, Full LCC } \\
\hline
\end{tabular}

\subsection{Analysed deficits for a next generation IPPD}

As indicated above, actual approaches focus a somewhat limited view to just one or two domains. Nevertheless, the complexity of future products needs to take into account an even more integrated view to all four domains, a fully matched product and production systems development, material selection and 
a systemic joint section design. For this purpose, and apart from Ashby's mainly unattached material selection methodology, a particularised material and joint selection and evaluation approach within the IPPD represents the genuine challenge. This is why an adequate joint section design for a holistically cross-component development view (except Kaspar et al. (2018) barely no systematic approaches focussing a cross-component view with all the influences back to the decision-making to materials, design and manufacturing choices) need to be associated to such an already intricate development procedure in section 3 .

\section{INTEGRATED VIEW}

Based on the reviewed approaches in section 2, the following framework integrates the domains product and production system development. Furthermore, the definition of materials and joints is covered in order to provide a holistic approach. First, a common terminology is introduced. On the basis of the results, a process model that addresses all domains is presented. The integration is completed by a method to represent solution combinations.

\subsection{Terminology}

The literature review in section 2 has shown, that the structure presented in Table 4 is very well suited to describe the different steps within the development processes. The original table (Stoffels et al., 2018) is extended by an appropriate joint definition according to the understanding from Kaspar et al. (2018). Phases with corresponding results for the four domains (product, production, material, joints) are arranged based on these rough categories.

Table 4. Integrated terminology of the development phases, based on Stoffels et al. (2018)

\begin{tabular}{|c|c|c|c|c|c|c|c|c|}
\hline & \multicolumn{2}{|c|}{ Product Definition } & \multicolumn{2}{|c|}{ Production Definition } & \multicolumn{2}{|c|}{ Material Definition } & \multicolumn{2}{|c|}{ Joint Definition } \\
\hline & Phase & Results & Phase & Results & Phase & Results & Phase & Results \\
\hline $\begin{array}{c}\text { Specification } \\
\text { Phase I }\end{array}$ & $\begin{array}{l}\text { D0: } \\
\text { Requirements } \\
\text { Definition }\end{array}$ & Requirements & $\begin{array}{l}\text { P0 Requirements } \\
\text { Definition }\end{array}$ & Requirements & $\begin{array}{l}\text { M0: } \\
\text { Requirements } \\
\text { Definition }\end{array}$ & Requirements & $\begin{array}{l}\text { J0: } \\
\text { Requirements } \\
\text { Definition }\end{array}$ & Requirements \\
\hline $\begin{array}{c}\text { Concept Phase } \\
\text { II }\end{array}$ & $\begin{array}{l}\text { D1: Functional } \\
\text { Design } \\
\text { D2: Principle } \\
\text { Design }\end{array}$ & \begin{tabular}{|l} 
Function \\
Strcutures \\
Principle \\
Solutions
\end{tabular} & $\begin{array}{l}\text { P1: Functional } \\
\text { Deisgn } \\
\text { P2: Technology } \\
\text { Selection }\end{array}$ & \begin{tabular}{|l|} 
Production \\
Functions \\
Technology \\
Chain
\end{tabular} & $\begin{array}{l}\text { M1: Property } \\
\text { Definition } \\
\text { M2: Class } \\
\text { Selection }\end{array}$ & $\begin{array}{l}\text { Material } \\
\text { Properties } \\
\text { Material } \\
\text { Subclasses }\end{array}$ & $\begin{array}{l}\text { J1: Property } \\
\text { Definition } \\
\text { J2: Principle } \\
\text { Design }\end{array}$ & $\begin{array}{l}\text { Joint Section \& } \\
\text { Properties } \\
\text { Principle } \\
\text { Solution \& } \\
\text { Technology } \\
\end{array}$ \\
\hline $\begin{array}{c}\text { Component-/ } \\
\text { Detailed Phase } \\
\text { III }\end{array}$ & $\begin{array}{l}\text { D3: Detailed } \\
\text { Design }\end{array}$ & $\begin{array}{l}\text { Product } \\
\text { Components }\end{array}$ & $\begin{array}{l}\text { P3: Detailed } \\
\text { Process Design \& } \\
\text { Production } \\
\text { System Design }\end{array}$ & \begin{tabular}{|l} 
Process \\
Structure \& \\
Production \\
System \\
Specification
\end{tabular} & $\begin{array}{l}\text { M3: } \\
\text { Specification }\end{array}$ & $\begin{array}{l}\text { Material } \\
\text { Specification }\end{array}$ & $\begin{array}{l}\text { J3: Detailed } \\
\text { Design \& } \\
\text { Specification }\end{array}$ & $\begin{array}{l}\text { Joint } \\
\text { Specification } \\
\text { (Elements \& } \\
\text { Process) }\end{array}$ \\
\hline $\begin{array}{c}\text { System } \\
\text { Integration } \\
\text { Phase IV }\end{array}$ & $\begin{array}{l}\text { D4: System } \\
\text { Integration }\end{array}$ & $\begin{array}{l}\text { Product } \\
\text { Specification }\end{array}$ & $\begin{array}{l}\text { P4: System } \\
\text { Integration }\end{array}$ & $\begin{array}{l}\text { Process and } \\
\text { Production } \\
\text { System } \\
\text { Specification }\end{array}$ & $\begin{array}{l}\text { M4: System } \\
\text { Integration }\end{array}$ & $\begin{array}{l}\text { Overall Material } \\
\text { Specification }\end{array}$ & & \\
\hline
\end{tabular}

\subsection{Integrated process model}

Using the results from the previous section, an integrated process model that considers the domains product, production, material and joints is developed (see Figure 2). Here, the process model is based on Stoffels (2017), whereas joints were added (see Figure 2). In this model, integrated steps complement the existing domain specific phases. Therein, solutions developed in the respective domain are collectively assessed and narrowed.

At the beginning, a general specification is separated into domain specific specification steps. In the concept phase, potential combinations of working principles, material subclasses and manufacturing technologies are analysed. Using combined technical, economic and ecological assessment criteria, unfavourable solutions are skipped.

Subsequently, the remaining combinations need to be further detailed. For each working principle, the deployment of potential geometries with corresponding joints is performed. These solution combinations are to be analysed and narrowed. The results are returned to the domain specific phases, checked and approved.

Within the domain specific phase, the concepts need to be detailed to components. Various designs with different materials arise over development time in the product domain and, for example, potential production resources are selected and developed in the production domain. The resulting properties are 
checked with appropriate simulation tools within the domains, while the interaction between design, production system, material and joints are analysed in the integrated component phase. An integrated assessment tool supports the selection of the best combination regarding technical, economic and ecological criteria. Thus, the results are returned to the domains again and the specification is finalised and the solutions are released.

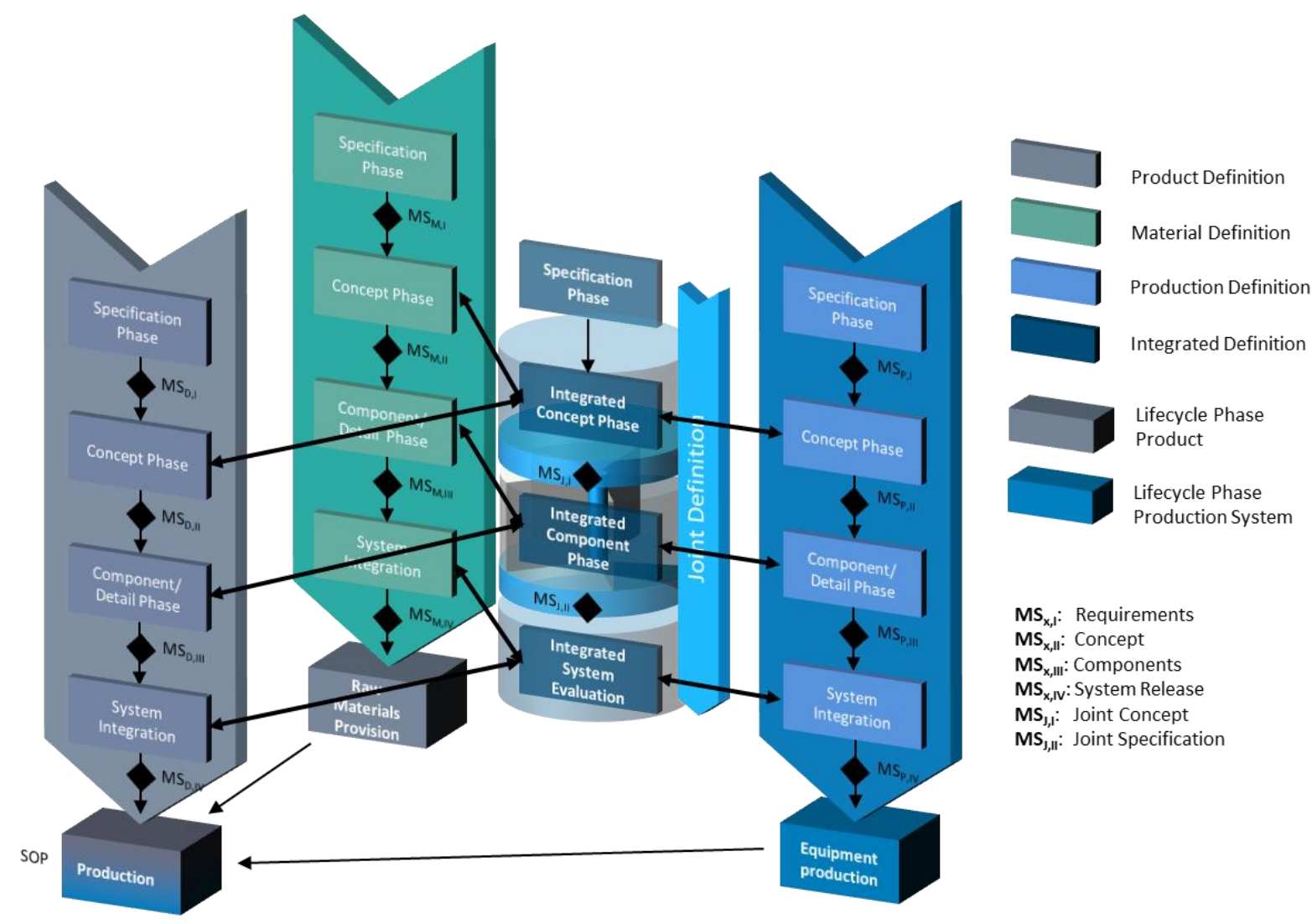

Figure 2. Integrated process model, based on (Stoffels, 2017)

In a last step, an integrated evaluation using life cycle analysis (LCA) and life cycle costing (LCC) provides detailed information of the results. It is only an analysis phase; if the requirements are not fulfilled, the previous processes have to be repeated. These data form the basis for very accurate analyses and enable an estimation of properties in early development phases for future products.

\section{METHODICAL SUPPORT}

In order to select or narrow solutions within the development process, an extensive tool is required. This tool needs to analyse the interactions between the solutions generated in each domain. For this reason, the authors developed the integrated morphological chart. Combinations of working principle, material subclass and manufacturing technology are assessed in the integrated concept phase regarding technical, economic and ecological criteria. Technical quality, costs, carbon dioxide emissions, LCA limit values, energy demand, resource criticality and so on are among these criteria. With progress of the development, combinations of components, materials and processes in combination with resources are assessed. Each combination is represented by a cube.

While, the first version does not consider the connection of various components, the tool needs to be extended to integrate joints. The approach is shown in Figure 3.

As described above, combinations of working principles, material subclasses and technologies are assessed and narrowed - unfavourable solutions are discarded. In a next step, each combination needs to be drilled down. Geometries that fulfil the requirements are generated and arranged over joints (light blue). A joint contains rough shape/geometry, a material (material subclass at this early stage) and a joining technology. With this approach, different solution structures are deployed. 


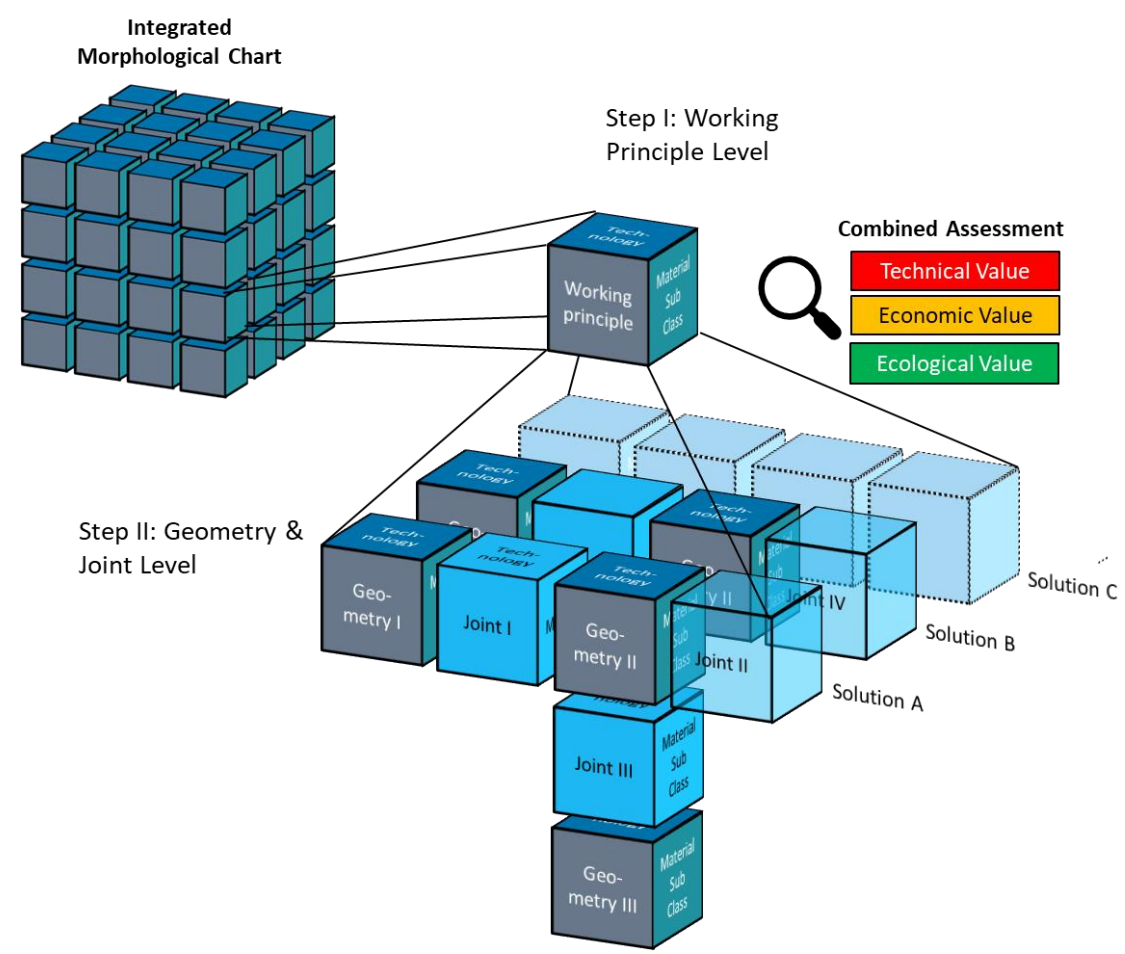

Figure 3. Methodical support

Next, a multicriterial assessment needs to be applied on the deployed solution structures in order to narrow the potential solutions and discard less appropriate solutions. As a solution consists of various elements, a score (weighted combination of technical, economic and ecological value) is assigned to each element/cube. Moreover, the approach of Kaspar et al. (2019) could enable an assessment of geometry-driven material/joining-combinations.

The total score of potential solution (S) is composed of the sum of all cubes. In a next step, the result needs to be normalised to the highest number of elements of a solution (cubes max). Now the score of each solution is in the same range and comparable. Solutions with a small number of elements (cubes) should be preferred (according to Boothroyd et al. (2002)) why they receive a bonus (weighted by gcc_max). This factor (a number between 0-1, e.g. $0=$ single item production, $0,5=$ small series, 1,0 series production) needs to be determined regarding product complexity, product type, quantity of output and so on.

$$
\text { Score }_{\text {Solution }, A}=\frac{\sum S(\text { cubes }, A)}{\text { number }(\text { cubes }, A)}+\frac{\operatorname{maxnumber}(\text { cubes }, x) \cdot g_{\text {CCmax }}}{\operatorname{number}(\text { cubes }, A)}
$$

In order to weight the relevance of geometry and joints, a factor $g(D, J)$ is introduced within the composed score of the solution (S). Thus, first the sum of the scores of all design cubes is divided by the number of design cubes and multiplied with factor $g(D, J)$. The joint cubes are weighted with $1-\mathrm{g}(\mathrm{D}, \mathrm{J})$. Then, the sum of both terms is multiplied with the total number of cubes in a solution.

$\sum S($ cubes,$A)=\left(\frac{\sum S(\text { cubes }, A, D) \cdot \mathrm{g}_{D, J}}{\text { number }(\text { cubes }, A, D)}+\frac{\sum S(\text { cubes }, A, J) \cdot\left(1-\mathrm{g}_{D, J}\right)}{\text { number }(\text { cubes }, A, J)}\right) \cdot$ number $($ cubes, $A)$

Using this calculation, all potential solutions are assessed and narrowed, which is exemplarily shown in the following example (Figure 4 and Figure 5) based on the schematic representation of Figure 3. 


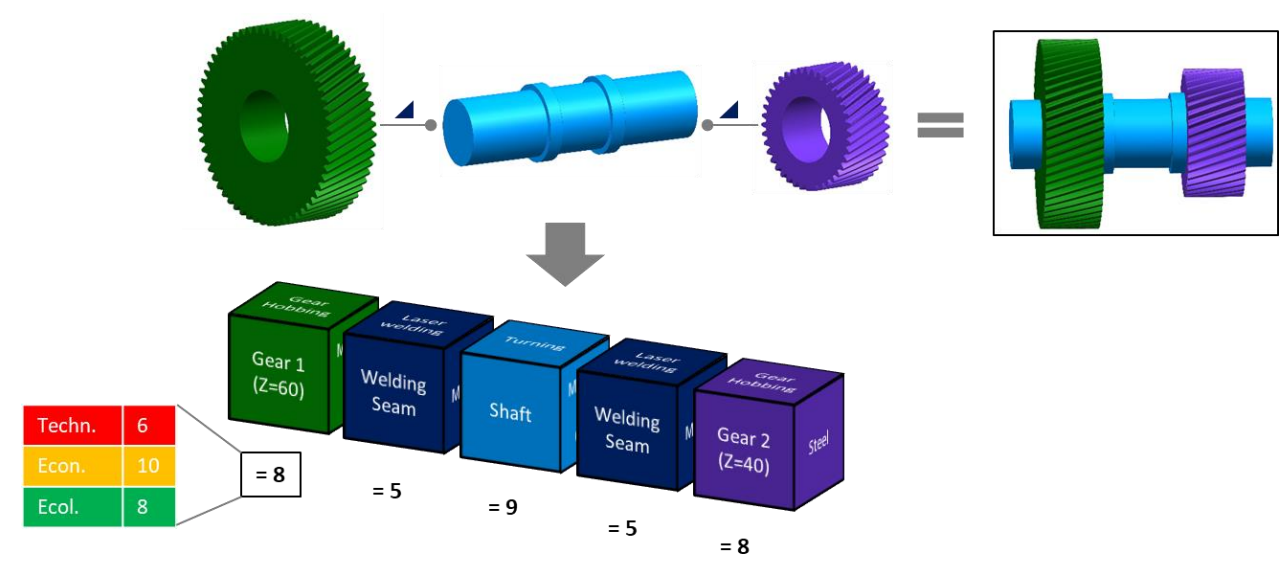

Figure 4. Application example "gear shaft" - Solution A

$$
\begin{aligned}
& \sum \operatorname{Score}(\text { cubes }, A)=\left(\frac{(8+9+8) \cdot 0,7}{3}+\frac{(5+5) \cdot(1-0,7)}{2}\right) \cdot 5=\mathbf{3 6}, \mathbf{6 6} \\
& \text { Score }_{\text {Solution }, A}=\frac{36,66 \text { points }}{5 \text { cubes }}+\frac{5 \text { cubes } \cdot 1}{5 \text { cubes }}=7,332+1=\mathbf{8}, \mathbf{3 3 2}
\end{aligned}
$$

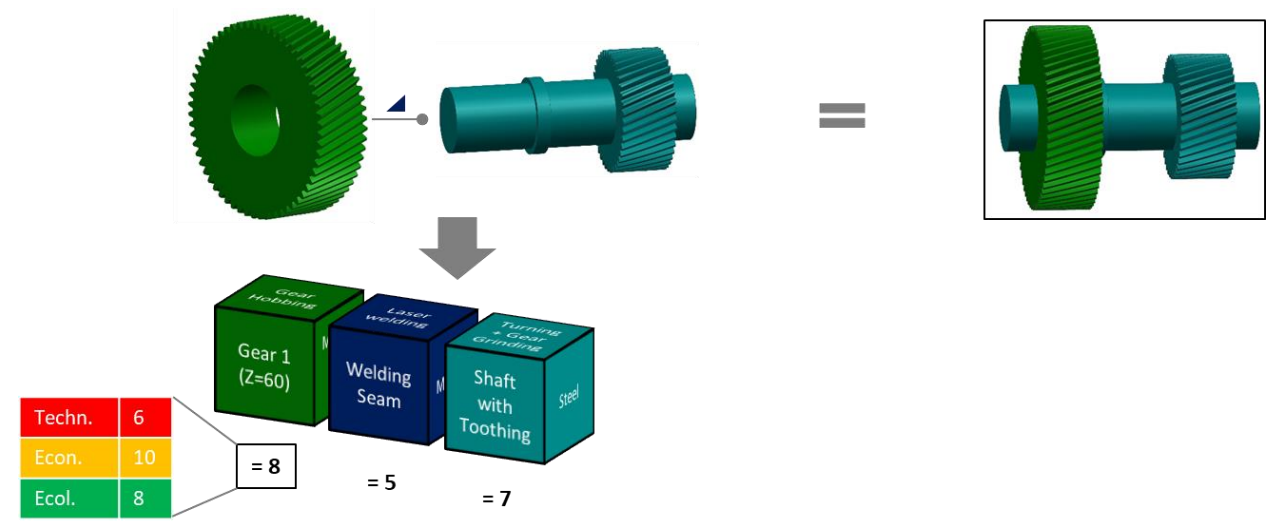

Figure 5. Application example "gear shaft" - Solution B

$$
\begin{aligned}
& \sum \operatorname{Score}(\text { cubes }, A)=\left(\frac{(8+7) \cdot 0,7}{2}+\frac{(5) \cdot(1-0,7)}{1}\right) \cdot 3=\mathbf{2 0 , 2 5} \\
& \text { Score }_{\text {Solution }, A}=\frac{20,25 \text { points }}{3 \text { cubes }}+\frac{5 \text { cubes } \cdot 1}{3 \text { cubes }}=6,75+1,66=\mathbf{8 , 4 1}
\end{aligned}
$$

Solution B has a higher total score in this example, which is selected for further considerations. As development continues, joints are further detailed using i.e. the approach of Rusitschka (2017).

\section{CONCLUSION}

An integrated consideration of product, production, material and joints is an essential key to competitive products, regarding technical, economic and ecological performance. As a basis for the integration, a common understanding of different development phases and results is needed. Thus, different approaches in the specific domains are reviewed and structured into categories.

Based on this description, the development of an integrated process model is possible. The key elements of this process are common assessment steps, where generated solutions are analysed for their technical, economic, and ecological performance. In order to support a required evaluation with methodical support, the integrated morphological chart is extended to consider joints. 
Next, the presented approach will be validated in future contributions with more comprehensive examples.

\section{REFERENCES}

Ashby, M. F. (2005): Materials selection in mechanical design. 3rd edition. Amsterdam, Boston: ButterworthHeinemann.

Akao, Y. (1990): Quality function deployment. Integrating customer requirements into product design. New York: Productivity Press.

Bellgran, M.; Säfsten, K. (2010): Production development. Design and operation of production systems. London: Springer.

Boothroyd, G.; Dewhurst, Peter; Knight, W. A. (2002): Product design for manufacture and assembly. 2nd edition. New York: M. Dekker.

Eversheim, W. (2002): Organisation in der Produktionstechnik. 4th edition. Berlin: Springer (VDI).

Granta Design 2020. https://www.grantadesign.com/language-home/industry/products/ces-selector/

Günter, S. (1994): Handbuch der Fertigungstechnik. München, Wien: Hanser.

Gu, P.; Rao, H.A; Tseng, M.M (2001): Systematic design of manufacturing systems based on axiomatic design approach. CIRP Annals - Manufacturing Technology 50 (1), pp. 299-304.

Hauser, J. R.; Clausing, D. (1988): The house of quality. Harvard Business Review Mai 1988, pp. 63-73.

Kaspar, J.; Choudry, S.A.; Vielhaber, M. Concurrent selection of material and joining technology - Holistically relevant aspects and its mutual interrelations in lightweight engineering. Procedia CIRP 72, 2018, pp. 780-785. https://doi.org/10.1016/j.procir.2018.03.093

Kaspar, Jerome; Revfi, Sven; Albers, Albert; Vielhaber, Michael (2019): Cross-component material and joining selection for functional lightweight design based on the extended target weighing approach - A detailed application example. Procedia CIRP 84, pp. 694-700. https://dx.doi.org/10.1016/j.procir.2019.04.192.

Minolla, W. (1975): Rationalisierung in der Arbeitsplanung. Schwerpunkt Organisation. Dissertation. Technische Hochschule Aachen, Aachen.

REFA (1990): Methodenlehre der Betriebsorganisation. Planung und Gestaltung komplexer Produktionssysteme. 2nd edition. München: Hanser.

Rusitschka, Fabian (2017): Methodik zur Auswahl von lösbaren Verbindungen in der variantenreichen Serienfertigung. Dissertation. Universität Stuttgart, Stuttgart. Online: http://d-nb.info/1153769859/34.

Stoffels, P.; Bähre, D.; Frey, G.; Vielhaber, M. (2015): Energy efficiency engineering - towards an integrated method framework for energy-oriented product and production development. In: Oral, A.Y. et al. (ed.): 2nd International Congress on Energy Efficiency and Energy Related Materials (ENEFM2014). Cham: Springer International Publishing (Springer Proceedings in Energy), pp. 291-297. https://doi.org/10.1007/978-3-31916901-9_35

Stoffels, P. (2017): Integrierte Definition von Produkt, Produktion und Material zur Steigerung der Ressourceneffizienz. Dissertation. Universität des Saarlandes, Saarbrücken. http://dx.doi.org/10.22028/D29126985

Stoffels, P.; Kaspar, J.; Bähre, D.; Vielhaber, M. (2018): Integrated product and production engineering approach A tool-based method for a holistic sustainable design, process and material selection. Procedia Manufacturing 21, pp. 790-797. https://dx.doi.org/10.1016/j.promfg.2018.02.185.

Suh, N. P. (1990): The principles of design. New York: Oxford University Press.

Suh, N. P. (1995): Design and operation of large systems. Journal of Manufacturing Systems 14 (3), pp. 203-213.

Ulrich, K. T.; Eppinger, S. D. (2008): Product design and development. 4th edition. Boston: McGraw-Hill/Irwin.

VDI Guideline VDI 2221, 1993-05: Methodik zum Entwickeln und Konstruieren technischer Systeme und Produkte. Berlin: Beuth Verlag.

VDI Guideline VDI 4499, 2008-02: Digital factory. Berlin: Beuth Verlag.

Vielhaber, M.; Stoffels, P. (2014): Product development vs. production development. Procedia CIRP 21, pp. 252-257. https://doi.org/10.1016/j.procir.2014.03.141

Weber, C. (2005): An extended theoretical approach to modelling products and product development processes. In: Bley, H.; Janssen, H.; Shpitalni M.; Krause, F.-L. (Hg.): Proceedings of the 2nd German-Israeli Symposium on Advances in Methods and Systems for Development of Products and Processes. 2nd German-Israeli Symposium on Advances in Methods and Systems for Development of Products and Processes. Berlin, 0708.07.2005. Stuttgart: Fraunhofer-IRB-Verlag, pp. 159-179.

Wu, B. (1994): Manufacturing systems design and analysis. Context and techniques. 2nd edition. London: Chapman \& Hall. 